\title{
PENGEMBANGAN MEDIA PRESENTASI VISUAL DENGAN PENDEKATAN KONTEKSTUAL DALAM PEMBELAJARAN MATEMATIKA DI SMP
}

\author{
Yulianti $^{1}$, Achmad Buchori ${ }^{2}$, Yanuar Hery Murtianto ${ }^{3}$ \\ ${ }^{1,2,3}$ Fakultas Pendidikan Matematika Ilmu Pengetahuan Alam dan Teknologi \\ Informasi Universitas PGRI Semarang \\ yuliantisnail@gmail.com ${ }^{1}$
}

\begin{abstract}
ABSTRAK
Pendidikan saat ini sedang mengalami perkembangan teknologi yang semakin pesat khususnya telepon seluler dan kepemilikan perangkat bergerak semakin meningkat. Untuk itulah dibutuhkan suatu media pembelajaran matematika yang dioperasikan pada komputer atau laptop dengan sistem operasi windows juga dapat dioperasikan pada perangkat android. Penelitian ini bertujuan untuk mengembangkan media pembelajaran matematika powerpoint for android. Metode yang digunakan ADDIE. (1) Analyze, analisis kebutuhan siswa menunjukkan siswa membutuhkan media pembelajaran. (2) Design, produk yang dihasilkan pada penelitian ini media presentasi visual powerpoint for android. (3) Development, media yang dikembangkan kemudian divalidasi oleh ahli media $89 \%$ dan ahli materi $84 \%$ sehingga dikatakan valid. (4) Implementation, tanggapan siswa di kelas VIII C tingkat pencapaian $88 \%$ berada pada kategori praktis. (5) Evaluation, data dalam penelitian ini terdiri dari data awal berupa nilai yang diperoleh melalui nilai ulangan harian. Data akhir berupa nilai yang diperoleh melalui posttest. Hasil dari posttest kedua kelas dilakukan uji kesamaan dua rata-rata (uji-t pihak kanan) didapat $\alpha=0,05$ diperoleh $t_{\text {tabel }}=1,66$ dan $t_{\text {hitung }}=3,589 t_{\text {hitung }}>t_{\text {tabel }}$ 3,589 $>1,66$ maka kesimpulan $\mathrm{H}_{0}$ ditolak. Jadi disimpulkan bahwa pengembangan media presentasi visual powerpoint for android dengan pendekatan kontekstual valid digunakan dan efektif serta praktis dari pada pendekatan saintifik pada pembelajaran matematika di SMP.
\end{abstract}

Kata Kunci: PowerPoint for Android, Pendekatan Kontekstual

\begin{abstract}
ABSTRAK
Education is currently experiencing rapid technological developments, especially mobile phones and mobile device ownership is increasing. For that we need a mathematics learning media that is operated on a computer or laptop with windows operating system can also be operated on the android device. This study aims to develop learning media mathematics powerpoint for android. The method used by ADDIE. (1) Analyze, student needs analysis shows students need learning media. (2) Design, the product produced in this research visual presentation media powerpoint for android. (3) Development, media developed then validated by $89 \%$ media experts and material experts $84 \%$ so it is said to be valid. (4) Implementation, student responses in class VIII C achievement level $88 \%$ are in the practical category. (5) Evaluation, the data in this study consists of preliminary data in the form of values obtained through daily test scores. The final data is the value obtained through posttest. The result of posttest of both classes was tested equality of two average (right-t test) got $\alpha=0,05$ obtained t_tabel $=1,66$ and $t$ hitung $=3,589$ (t_count> $t)$ _table 3,589>1,66 then conclusion HO refused. So it is concluded that the development of visual presentation media powerpoint for android with a valid contextual approach is used and effective and practical rather than the scientific approach to mathematics learning in junior high.
\end{abstract}

Keyword: PowerPoint for Android, Contextual approach 


\section{PENDAHULUAN}

Ilmu pengetahuan dan teknologi sekarang ini semakin maju. Salah satunya akibat dari globalisasi, yang memicu timbulnya berbagai macam persaingan dalam berbagai bidang kehidupan, khususnya dalam dunia pendidikan matematika. Matematika sebagai suatu disiplin ilmu yang secara jelas mengandalkan proses berpikir dipandang sangat baik untuk diajarkan pada siswa, di dalamnya terkandung berbagai aspek yang secara substansial menuntun siswa untuk berpikir logis menurut pola dan aturan yang telah tersusun secara baku, sehingga seringkali tujuan utama dari mengajarkan matematika tidak lain untuk membiasakan agar siswa mampu berpikir logis, kritis dan sistematis (Syahbana, 2012: 46).

Berdasarkan hasil wawancara dengan salah satu guru matematika di SMPN 1 Lebakbarang, menyatakan bahwa guru matematika di SMP menjelaskan materi menggunakan media sederhana yaitu powerpoint tidak menggunakan media modern seperti macromedia flash, lectora, Prezi dan media lainnya. Beberapa guru melakukan sedikit persiapan yang tepat dan tidak menggunakan pengalaman siswa sebagai titik awal pengajaran siswa.

Guru cenderung menggunakan contoh abstrak saat membahas pengajaran matematika tidak membantu siswa untuk melihat koneksi matematika ke kehidupan sehari-hari siswa (Makari, 2013: 73). Penekanan guru pada proses pembelajaran matematika harus seimbang antara melakukan (doing) dan berpikir (thinking). Guru harus dapat menumbuhkan kesadaran siswa dalam melakukan aktivitas pembelajaran sehingga siswa tidak hanya memiliki keterampilan melakukan sesuatu tetapi harus memahami mengapa aktivitas itu dilakukan dan apa implikasinya (Murtianto, 2014: 78). Oleh karena itu, diperlukan adanya inovasi dalam pembelajaran matematika yang berubah dalam strategi pembelajaran termasuk pendekatan pembelajaran, kemungkinan siswa akan belajar lebih baik jika diciptakan lingkungan alam, belajar akan lebih bermakna jika siswa memiliki apa yang mereka pelajari, maka salah satu pendekatan efektif dalam proses belajar adalah pendekatan kontekstual (Agustan S., 2016: 119).

Pendekatan kontekstual adalah konsep yang membantu guru untuk belajar dan untuk mengasosiasikan pembelajaran dengan situasi dunia nyata siswa dan 
mendorong siswa membuat hubungan antara pengetahuan yang dimiliki dengan penerapannya dalam kehidupan mereka sebagai anggota keluarga dan masyarakat (Ekowati, dkk., 2015: 82). Penggunaan media dalam pembelajaran dengan menggunakan pendekatan kontekstual akan memudahkan guru untuk menyampaikan pesan/informasi kepada siswa dengan lebih jelas, menarik dan inovatif. Penggunaan media pembelajaran merupakan salah satu upaya untuk menciptakan pembelajaran yang lebih bermakna dan berkualitas. Untuk meningkatkan kualitas pembelajaran dibutuhkan upaya alternatif sehingga dapat meningkatkan hasil yang dicapai dalam pembelajaran tersebut (Nursit, 2015: 39). Microsoft powerpoint dipakai oleh guru sebagai media untuk menyampaikan bahan ajar kepada siswa. Beberapa hal yang menjadikan powerpoint ini menarik untuk digunakan adalah berbagai kemampuan pengolahan teks, warna, dan gambar, serta animasi-animasi yang bisa diolah sendiri sesuai kreatifitas. Dengan powerpoint ini siswa akan lebih tertarik dan perhatiannya terfokus, sehingga akan berimbas pada hasil belajar yang efektif (Suminto, 2016: 32).

Beberapa dekade terakhir ini perkembangan teknologi semakin pesat khususnya telepon seluler dan kepemilikan perangkat bergerak semakin meningkat. Hal ini disebabkan semakin terjangkaunya harga perangkat-perangkat ini oleh masyarakat (Amin, 2015: 13). Pemanfaatan perangkat mobile dalam dunia pendidikan secara umum dan pembelajaran matematika secara khusus masih minim. Hal ini menunjukkan perlunya menginovasi media presentasi yang dioperasikan pada komputer atau laptop dengan sistem operasi windows juga dapat dioperasikan pada perangkat android. Penggunaan handphone sebagai telekomunikasi dewasa ini masih belum dimanfaatkan dengan optimal oleh pendidikan. Penggunaan handphone sebagai media pembelajaran tentu menarik dan praktis, karena dapat diakses di mana saja dan kapan saja (Buchori, 2015: 114). Oleh karena itu, pengembangan PowerPoint For Android sebagai media pembelajaran matematika perlu untuk dikembangkan.

Microsoft PowerPoint adalah software atau perangkat lunak untuk membuat animasi yang menarik dalam waktu yang cepat (Suprapti, 2016: 57), dan Android memberikan platform terbaik untuk membuat aplikasi untuk pengguna 
android di manapun dan juga pasar terbuka (Jawale, 2015: 732). Dengan menyediakan platform pengembangan terbuka, android menawarkan kemampuan pengembang untuk membangun aplikasi sangat kaya dan aplikasi inovatif. Pengembang bebas memanfaatkan perangkat ini perangkat keras, akses informasi lokasi, jalankan layanan latar belakang, atur alarm, tambahkan pemberitahuan ke Status bar, dan masih banyak lagi (Banu dan Vijayakumar, 2013: 138).

Berdasarkan uraian di atas, maka peneliti termotivasi untuk melakukan penelitian "Pengembangan Media Presentasi Visual PowerPoint for Android dengan Pendekatan Kontekstual dalam Pembelajaran Matematika di SMP”.

\section{METODE PENELITIAN}

Metode yang digunakan dalam penelitian ini adalah pengembangan atau development and research (R\&D) (Putra, 2013: 70), dalam hal ini penelitian pengembangan dilaksanakan untuk menghasilkan perangkat pembelajaran media presentasi visual powerpoint for android dengan pendekatan kontekstual dalam pembelajaran matematika yaitu materi relasi dan fungsi kelas VIII SMPN 1 Lebakbarang. Adapun perangkat pembelajaran yang dikembangkan meliputi: Rencana Pelaksanaan Pembelajaran (RPP), Media Presentasi Microsoft Power Point for Android, dan Evaluasi.

Prosedur pengembangan yang digunakan untuk mengembangkan perangkat pembelajaran dalam penelitian ini, mengacu pada model ADDIE (Pribadi, 2010: 125). Proses pengembangan instrumen ini terdiri dari lima tahap yaitu: (A)nalisis, (D)esign, (D)evelopment, (I)mplementation, dan (E)valuation. Metode pengembangan ADDIE dengan komponen-komponennya yang digunakan dalam penilitian ini dapat diperlihatkan pada gambar berikut: 


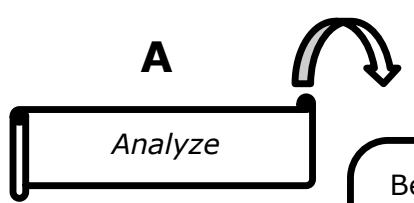

Berdasarkan tahap model ADDIE, tahap yang pertama dilakukan adalah analisis (analyze) yaitu analisis kebutuhan (need analyze) merupakan langkah yang diperlukan untuk menentukan kemampuan-kemampuan atau kompetensi yang perlu dipelajari oleh siswa untuk meningkatkan kinerja atau hasil belajar.

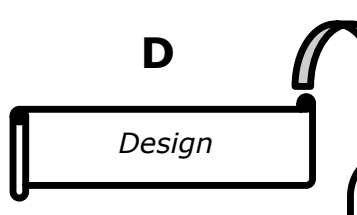

Desain merupakan langkah kedua dari model ADDIE. Pada tahap ini peneliti menentukan konsep dari media presentasi visual yang akan dibangun. Pada tahapan ini dibuat gambaran umum tentang media pembelajaran berdasarkan analisa sebelumnya. Selanjutnya menentukan objek multimedia yang akan digunakan, serta menentukan bentuk atau hasil media presentasi visual yang diinginkan.

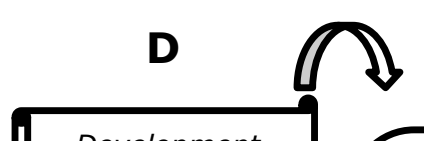

Pengembangan merupakan langkah ketiga dari model ADDIE yang berisi kegiatan realisasi rancangan produk. Pada tahap ini, peneliti melanjutkan pembuatan produk berdasarkan desain yang telah dibuat. Pada tahap awal pembuatan media, peneliti mengkonsultasikan kepada dosen pembimbing untuk revisi dan tindak lanjut tahap demi tahap. Media yang telah dihasilkan kemudian dikaji oleh ahli media dan ahli materi. Hasil penilaian oleh ahli media dan ahli materi digunakan untuk pedoman revisi sehingga akan dihasilkan media yang layak uji baik dari segi tampilan maupun materi.

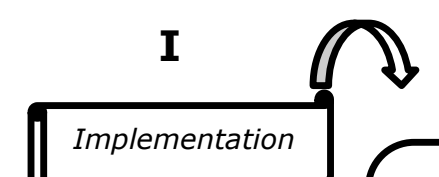

Implementasi merupakan tahap keempat dalam model ADDIE. Pada tahap ini, akan dilaksanakan program pembelajaran dengan menerapkan desain atau spesifikasi program pembelajaran. Setelah dinyatakan layak uji oleh ahli media dan ahli materi, maka peneliti akan menggunakan media presentasi visual powerpoint for android dengan pendekatan kontekstual dalam pembelajaran matematika pada situasi nyata di kelas.

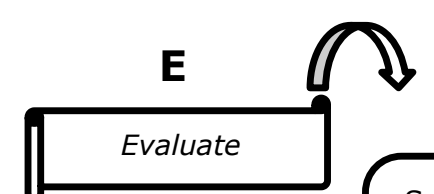

Setelah kegiatan pembelajaran dilakukan pada kelas kontrol dan kelas eksperimen, maka dilakukan evaluasi program pembelajaran dan dilakukan analisis terhadap data keefektifan. Tahap ini merupakan tahap kelima (terakhir) dari ADDIE yaitu Evaluate.

Bagan 1. Metode Pengembangan ADDIE 


\section{HASIL DAN PEMBAHASAN}

\section{Analyze}

Sebelum melaksanakan penelitian, peneliti melakukan observasi terhadap media pembelajaran yang digunakan dan menganalisis kurikulum yang akan dikembangkan materinya. Berdasarkan hasil wawancara dengan salah satu guru matematika di SMP N 1 Lebakbarang yaitu Bapak Loso, menyatakan bahwa guru matematika di SMP menjelaskan materi menggunakan media sederhana yaitu powerpoint tidak menggunakan media modern seperti macromedia flash, lectora, Prezi dan media lainnya. Pada penelitian ini media yang akan dikembangkan adalah PowerPoint for Android dengan memanfaatkan aplikasi iSpring Pro yaitu salah satu tool yang mengubah file presentasi menjadi bentuk flash.

Media pembelajaran berbasis PowerPoint dan iSpring Pro memiliki kemudahan dari segi proses pembuatan dan mampu menampilkan berbagai program aplikasi seperti slide, grafik, gambar, animasi, audio, dan video. Selain itu, guru juga sudah mengenal program PowerPoint bahkan masih sederhana dalam membuat dan menggunkan media PowerPoint dalam pembelajaran di sekolah. Media PowerPoint dan iSpring Pro memberi kesempatan bagi guru untuk dapat dengan mudah membuat media presentasi yang mudah dan menarik.

Berdasarkan hasil observasi di SMP N 1 Lebakbarang, beberapa siswa memiliki komputer atau laptop di rumah dan keseluruhannya memiliki telepon seluler (handphone). Namun, perangkat mobile ini pada umumnya hanya digunakan untuk SMS, telepon, chatting, internet dan hiburan seperti permainan dan musik, di sisi lain, pemanfaatan perangkat mobile dalam dunia pendidikan secara umum dan pembelajaran matematika secara khusus masih minim. Hal ini menunjukkan perlunya menginovasi media presentasi yang dioperasikan pada komputer atau laptop dengan sistem operasi windows juga dapat dioperasikan pada perangkat android. Oleh karena itu, pengembangan PowerPoint For Android sebagai media pembelajaran matematika perlu untuk dikembangkan. Pada penelitian ini media yang akan dikembangkan adalah PowerPoint for Android dengan materi relasi dan fungsi kelas VIII semester 1 tahun pelajaran 2016/2017. 


\section{Design}

Produk yang akan dihasilkan dalam penelitian ini adalah media presentasi visual PowerPoint for Android dengan pendekatan kontekstual pada materi relasi dan fungsi kelas VIII. Keistimewaan media yang dikembangkan ini adalah powerpoint yang bisa menjalankan tombol navigasi pada android, tampilan slide materi seperti e-book, soal evaluasi yang interaktif karena terdapat feedback jawaban yang benar ketika siswa selesai mengerjakan soal evaluasi dan hasil nilai dari siswa secara otomatis terkirim ke e-mail pengembang. Selain itu, juga terdapat instrument music saat media dijalankan, sehingga media lebih menarik. Berikut adalah desain produk yang dibuat:
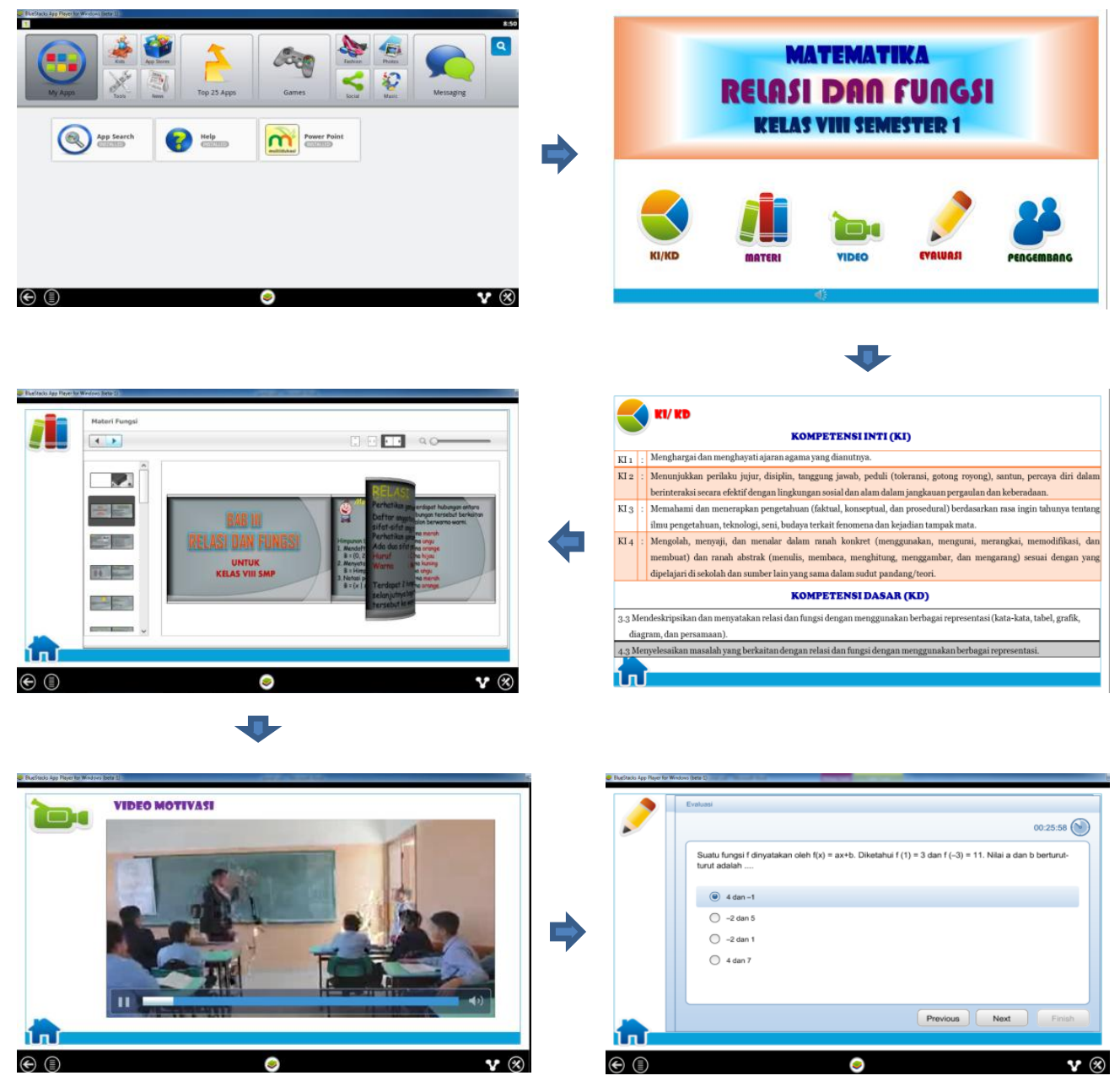

Gambar 1. Media PowerPoint for Android 


\section{Development}

Setelah dibuat rancangan desain produk dan kegiatan belajar mengajar, maka dibuat perangkat pembelajaran dengan media pembelajaran yang dikembangkan. Setelah di buat perangkat pembelajaran maka hasil dari media pembelajaran yang telah dibuat dikaji oleh ahli media dan ahli materi. Uji validasi media dilakukan setelah mendapatkan persetujuan dari dosen pembimbing. Dengan memberikan lembar validasi yang terbagi menjadi 4 aspek yaitu: aspek aplikasi, aspek kreatif, aspek inovatif dan aspek komunikasi visual. Dari keempat aspek tersebut total terdapat 20 indikator penilaian. Ahli media pada penelitian ini adalah Ibu Ika Menarianti, M.Kom. dosen pendidikan Teknologi Informasi di Universitas PGRI Semarang, dan Bapak Slamet Subchi Achmad, S.Pd., guru TIK di SMP N 1 Lebakbarang memperoleh hasil sebagai berikut:

Tabel 1. Analisis Validasi Media

\begin{tabular}{|c|c|c|c|c|c|c|c|c|}
\hline \multirow[t]{2}{*}{ No } & \multirow[t]{2}{*}{ Aspek } & \multirow{2}{*}{$\begin{array}{l}\text { Skor yang } \\
\text { diharapkan }\end{array}$} & \multicolumn{2}{|c|}{ Ahli } & \multicolumn{2}{|c|}{$\begin{array}{c}\text { Presentase } \\
\text { Ahli }\end{array}$} & \multirow{2}{*}{$\begin{array}{c}\text { Rata-rata } \\
\text { Presentase } \\
\text { Ahli }\end{array}$} & \multirow[t]{2}{*}{ Kriteria } \\
\hline & & & 1 & 2 & 1 & 2 & & \\
\hline 1 & Aplikasi & 30 & $\begin{array}{l}2 \\
8\end{array}$ & $\begin{array}{l}2 \\
9\end{array}$ & $93 \%$ & $97 \%$ & $95 \%$ & $\begin{array}{c}\text { Sangat } \\
\text { baik }\end{array}$ \\
\hline 2 & Kreatif & 20 & $\begin{array}{l}1 \\
6\end{array}$ & $\begin{array}{l}1 \\
8\end{array}$ & $80 \%$ & $90 \%$ & $85 \%$ & $\begin{array}{c}\text { Sangat } \\
\text { baik }\end{array}$ \\
\hline 3 & Inovatif & 25 & $\begin{array}{l}2 \\
0\end{array}$ & $\begin{array}{l}2 \\
2\end{array}$ & $80 \%$ & $88 \%$ & $84 \%$ & $\begin{array}{c}\text { Sangat } \\
\text { baik }\end{array}$ \\
\hline \multirow[t]{2}{*}{4} & $\begin{array}{c}\text { Komunikasi } \\
\text { Visual }\end{array}$ & 25 & $\begin{array}{l}2 \\
1\end{array}$ & $\begin{array}{l}2 \\
4\end{array}$ & \multirow[t]{2}{*}{$84 \%$} & \multirow[t]{2}{*}{$96 \%$} & \multirow[t]{2}{*}{$90 \%$} & $\begin{array}{c}\text { Sangat } \\
\text { baik }\end{array}$ \\
\hline & Jumlah & 100 & $\begin{array}{l}8 \\
5\end{array}$ & $\begin{array}{l}9 \\
3\end{array}$ & & & & \\
\hline \multicolumn{2}{|c|}{ Jumlah Total } & \multicolumn{3}{|c|}{178} & & & & \\
\hline \multicolumn{2}{|c|}{$\begin{array}{c}\text { Presentase Total } \\
\text { Kriteria }\end{array}$} & \multicolumn{3}{|c|}{$\begin{array}{c}89 \% \\
\text { Sangat baik }\end{array}$} & & & & \\
\hline
\end{tabular}

Pada tabel 1. jelas terlihat bahwa semua aspek yang diajukan kepada ahli media telah menempatkan diri pada kriteria sangat layak karena Aspek Aplikasi (95\%), Aspek Kreatif (85\%), Aspek Inovatif (84\%), Aspek Komunikasi Visual (90\%), dan persentase total $89 \%$. Setelah dikonversikan dengan tabel konversi skala, presentase tingkat pencapaian $89 \%$ berada pada kualifikasi layak. 
Uji validasi ahli materi dilakukan setelah mendapatkan persetujuan dari dosen pembimbing. Dengan memberikan lembar validasi yang terbagi menjadi 2 aspek yaitu: aspek substansi materi dan aspek kelayakan bahasa. Dari kedua aspek tersebut total terdapat 17 indikator penilaian. Ahli materi pada penelitian ini adalah Ibu Sugiyanti, M.Pd. dosen Pendidikan Matematika di Universitas PGRI Semarang dan Bapak Loso A.Md.Pd. guru matematika di SMP N 1 Lebakbarang memperoleh hasil sebagai berikut:

Tabel 2. Analisis Validasi Materi

\begin{tabular}{|c|c|c|c|c|c|c|c|c|}
\hline \multirow[t]{2}{*}{ No } & \multirow[t]{2}{*}{ Aspek } & \multirow{2}{*}{$\begin{array}{l}\text { Skor yang } \\
\text { diharapkan }\end{array}$} & \multicolumn{2}{|c|}{ Ahli } & \multicolumn{2}{|c|}{$\begin{array}{c}\text { Presentase } \\
\text { Ahli }\end{array}$} & \multirow{2}{*}{$\begin{array}{c}\text { Rata-rata } \\
\text { Presentase } \\
\text { Ahli }\end{array}$} & \multirow[t]{2}{*}{ Kriteria } \\
\hline & & & 1 & 2 & 1 & 2 & & \\
\hline \multirow[t]{2}{*}{1} & Substansi & \multirow{2}{*}{60} & 5 & 5 & \multirow{2}{*}{$83 \%$} & \multirow{2}{*}{$87 \%$} & \multirow{2}{*}{$85 \%$} & \multirow{2}{*}{$\begin{array}{c}\text { Sangat } \\
\text { baik }\end{array}$} \\
\hline & Materi & & 0 & 2 & & & & \\
\hline \multirow[t]{4}{*}{2} & Kelayakan & 25 & 2 & 2 & \multirow{4}{*}{$80 \%$} & \multirow{4}{*}{$84 \%$} & \multirow{4}{*}{$82 \%$} & Sangat \\
\hline & Bahasa & 25 & 0 & 1 & & & & baik \\
\hline & \multirow[t]{2}{*}{ Jumlah } & \multirow{2}{*}{85} & 7 & 7 & & & & \\
\hline & & & 0 & 3 & & & & \\
\hline \multicolumn{2}{|c|}{ Jumlah Total } & \multicolumn{3}{|l|}{143} & & & & \\
\hline \multicolumn{2}{|c|}{ Presentase Total } & \multicolumn{3}{|c|}{$84 \%$} & & & & \\
\hline \multicolumn{2}{|c|}{ Kriteria } & \multicolumn{3}{|c|}{ Sangat baik } & & & & \\
\hline
\end{tabular}

Pada tabel 2. jelas terlihat bahwa semua aspek yang diajukan kepada ahli materi telah menempatkan diri pada kriteria sangat layak karena Aspek Subtansi Materi (85\%), Aspek Bahasa (82\%), dan persentase total 84\%. Setelah dikonversikan dengan tabel konversi skala, presentase tingkat pencapaian $84 \%$ berada pada kualifikasi layak.

\section{Implementation}

Setelah produk divalidasi oleh ahli media dan materi langkah selanjutnya adalah menyebarkan angket respon siswa uji kelompok kecil. Setelah di peroleh prensetase respon siswa memenuhi kategori baik maka di lanjutkan dengan menguji cobakan media pembelajaran pada kegiatan pembelajaran di kelas eksperimen. Tahap implementasi ini merupakan tahap ke empat dari ADDIE. Pada tahap implementasi, akan dilaksanakan program pembelajaran dengan 
menerapkan desain atau spesifikasi program pembelajaran. Setelah dinyatakan layak uji oleh ahli media dan ahli materi, maka peneliti akan menggunakan media presentasi visual powerpoint for android dengan pendekatan kontekstual dalam pembelajaran matematika pada situasi nyata di kelas. Media pembelajaran ini ditanggapi oleh 38 siswa yang berasal dari kelas VIII C. Siswa menanggapi media ini dengan cara mengisi angket yang diberikan peneliti untuk diisi siswa. Pada proses anlisis selanjutnya dilakukan analisis keseluruhan dalam penilaian tanggapan oleh siswa sehingga diperoleh persentase total $88 \%$. Setelah dikonversikan dengan tabel konversi skala, presentase tingkat pencapaian $88 \%$ berada pada kualifikasi praktis.

\section{Evaluate}

Setelah kegiatan pembelajaran dilakukan pada kelas kontrol dan kelas eksperimen, maka dilakukan evaluasi program pembelajaran dan dilakukan analisis terhadap data keefektifan. Tahap ini merupakan tahap kelima (terakhir) dari ADDIE yaitu Evaluate.

Setelah melakukan post test dari soal tes instrument penelitian pada kelas eksperimen dan kontrol, dari perhitungan diperoleh rata-rata nilai post test kelas eksperimen 73,263 dan kelas kontrol 63,553 $n_{1}=38$ dan $n_{2}=38$ dan varians gabungan kedua kelas $=139,1184$ sehingga didapat $\mathrm{s}=11,795$ sehingga diperoleh $t_{\text {hitung }}$ yaitu 3,589. Hasil tersebut kemudian dikonsultasikan dengan $t_{\text {tabel }}$. Dari tabel distribusi t dengan dk yaitu 74 dan $\alpha$ yaitu $5 \%$ diperoleh $t_{\text {tabel }}$ yaitu 1,66. Karena $t_{\text {hitung }}>t_{\text {tabel }}$ yaitu 3,589 $>1,66$ maka $\mathrm{H}_{0}$ ditolak dan $\mathrm{H}_{\mathrm{a}}$ diterima, sehingga dapat disimpulkan rata-rata hasil belajar siswa kelas eksperimen setelah diberi perlakuan dengan media pembelajaran yaitu media presentasi visual powerpoint for android dengan pendekatan kontekstual lebih baik dari rata-rata nilai kelas kontrol.

Suatu kelas dikatakan tuntas secara klasikal jika KKM dikelas tersebut terdapat $\geq 70 \%$ siswa. Persentase ketuntasan belajar klasikal untuk kelas eksperimen sebesar 83,33\% dan untuk kelas kontrol sebesar 66,67\%. Hal ini diperoleh dari tes evaluasi kelas eksperimen 25 siswa yang tuntas dari 38 dan kelas kontrol 20 siswa yang tuntas dari 38. Untuk rata-rata kelas eksperimen 
sebesar 73,263 dan rata-rata kelas kontrol sebesar 63,553. Jadi, rata-rata kelas eksperimen lebih besar dari pada rata-rata kelas kontol. Karena ketiga indikator ketuntasan belajar terpenuhi maka dapat dikatakan pembelajaran menggunakan media presentasi visual powerpoint for android dengan pendekatan kontekstual lebih efektif dari pada pendekatan saintifik.

\section{SIMPULAN}

Dihasilkan media presentasi visual PowerPoint for Android dengan pendekatan kontekstual yang disesuaikan untuk pembelajaran matematika di SMP dan model pengembangan ADDIE. Berdasarkan pengujian dari ahli media dan ahli materi menunjukan bahwa media presentasi visual PowerPoint for Android dengan pendekatan kontekstual merupakan media yang layak digunakan oleh siswa, dengan nilai dari ahli media yaitu $89 \%$ dan ahli materi yaitu $84 \%$, praktis digunakan dibuktikan dari hasil penilaian tanggapan siswa kelas eksperimen yaitu $88 \%$, dan efektif dibuktikan dari hasil uji t satu pihak kanan memperoleh thitung $>$ tabel yaitu 3,589 > 1,66 maka $\mathrm{H}_{0}$ ditolak. Dan kemudian dibuktikan dari rata-rata kelas eksperimen sebesar 73,263 dan rata-rata kelas kontrol 63,553. Jadi rata-rata kelas eksperimen lebih besar dari pada rata-rata kelas kontrol sehingga dikatakan pembelajaran menggunakan media presentasi visual PowerPoint for Android dengan pendekatan kontekstual lebih efektif dari pada pendekatan saintifik.

\section{DAFTAR PUSTAKA}

Agustan, S. 2016. Usage of Contextual Approach to Increase Student's Understanding in Learning Mathematics. IOSR Journal of Mathematics, 12 (6), 118-122.

Amin, Ahmad Kholiqul dan Novi Mayasari. 2015. Pengembangan Media Pembelajaran Berbentuk Aplikasi Android Berbasis Weblog Untuk Meningkatkan Hasil Belajar Mahasiswa Pendidikan Matematika Ikip Pgri Bojonegoro. Magistra, 94 (27), 12-23.

Arikunto, Suharsimi. 2013. Dasar-dasar Evaluasi Pendidikan. Jakarta: Bumi Aksara.

Banu, Sakila dan Vijayakumar, Kanakasabapathi. 2013. An Ide For Android Mobile Phones With Extended Functionalities Using Best Developing Methodologies. International Journal of Computer Networks \& Communications, 5 (4), 131-145. 
Buchori, Achmad, dkk. 2015. Pengembangan Mobile Learning Dengan Model Tapps Pada Materi Barisan Dan Deret Kelas X Semester I di SMA Nasima Semarang. JKPM, 2 (2), 1-7.

Ekowati, Ch. Krisnandari, dkk. 2015. The Application of Contextual Approach in Learning Mathematics to Improve Students Motivation At SMPN 1 Kupang. International Education Studes, 8 (8), 81-86.

Jawale, Damini S., dkk. 2015. Android based PC Remote Control using Wi-Fi. International Journal of Computer Science and Mobile Computing, 4 (3), 732-738.

Makari, K. Eben. 2013. The Use Of Contextualised Teaching And Learning In Grade 11 and 12 Mathematics Classrooms In Gobabis, Namibia. Journal for Studies in Humanities and Social Sciences, 2 (1), 73-85.

Murtianto, Yanuar Hery. 2014. Pengembangan Strategi Pembelajaran Matematika SMP Berbasis Pendekatan Metakognitif ditinjau dari Regulasi diri Siswa. AKSIOMA. 5(2).

Nursit, Isbadar. 2015. Pengembangan Multimedia Interaktif Berbasis Power Point (Macro-Enabled) Pada Mata Kuliah Geometri Euclid Dalam Pembelajaran Matematika. Jurnal Media Pendidikan Matematika "JMPM", 4 (1), 38-46.

Pribadi, Benny. 2010. Model Desain Sistem Pembelajaran. Jakarta: PT. Dian Rakyat.

Putra, Nusa. 2013. Research \& Development Penelitian dan Pengembangan: Suatu Pengantar. Jakarta: PT. RajaGrafinda Persada.

Sandy, Teguh Arie. 2017. PowerPoint For Android.Yogyakarta: CV Budi Utama. Sudjana. 2005. Metode Statistika. Bandung: PT Tarsito Bandung.

Suminto. 2016. Ektivitas Model Pembelajaran Open Ended Dengan Media Power Poin Pada Materi Lingkaran Dan Bangun Ruang Kubus Dan Balok. Jurnal e-DuMath, 2 (1), 28-37.

Suprapti, Endang. 2016. Pengembangan Perangkat Pembelajaran Matematika Model Kooperatif Tipe Stad Dengan Media Powerpoint Ispring Pada Materi Jajargenjang, Layang-Layang, Dan Trapesium Di Kelas VII SMP. Journal of Mathematics Education, Science and Technology, 1 (1), $57-68$.

Syahbana, Ali. 2012. Peningkatan Kemampuan Berpikir Kritis Matematis Siswa SMP Melalui Pendekatan Contextual Teaching And Learning. Edumatica, 2 (1), 45-57. 